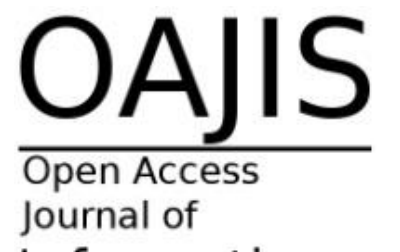

Information

Systems

is.its.ac.id/pubs/oajis/
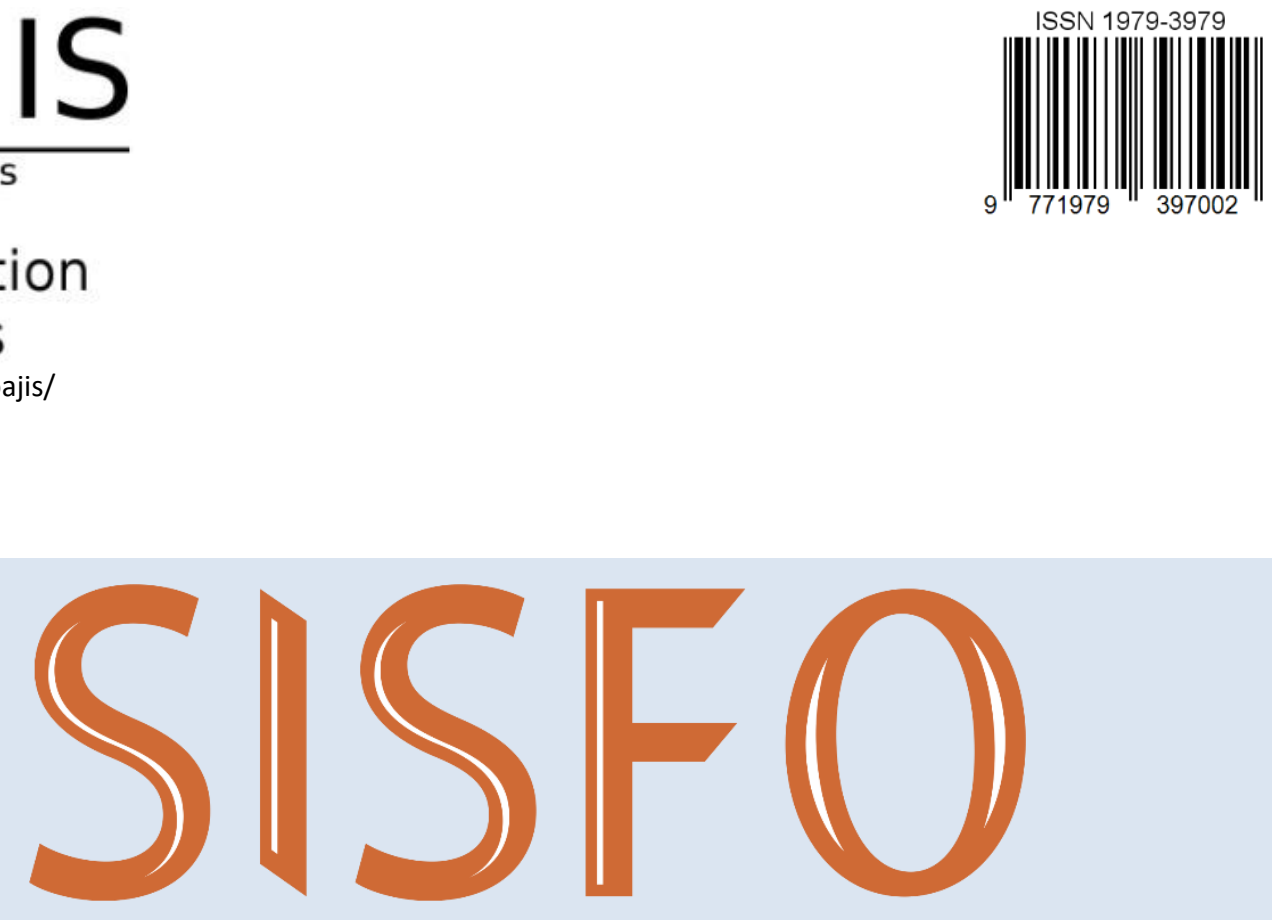

Inspirasi Profesional Sistem Informasi

\section{People}

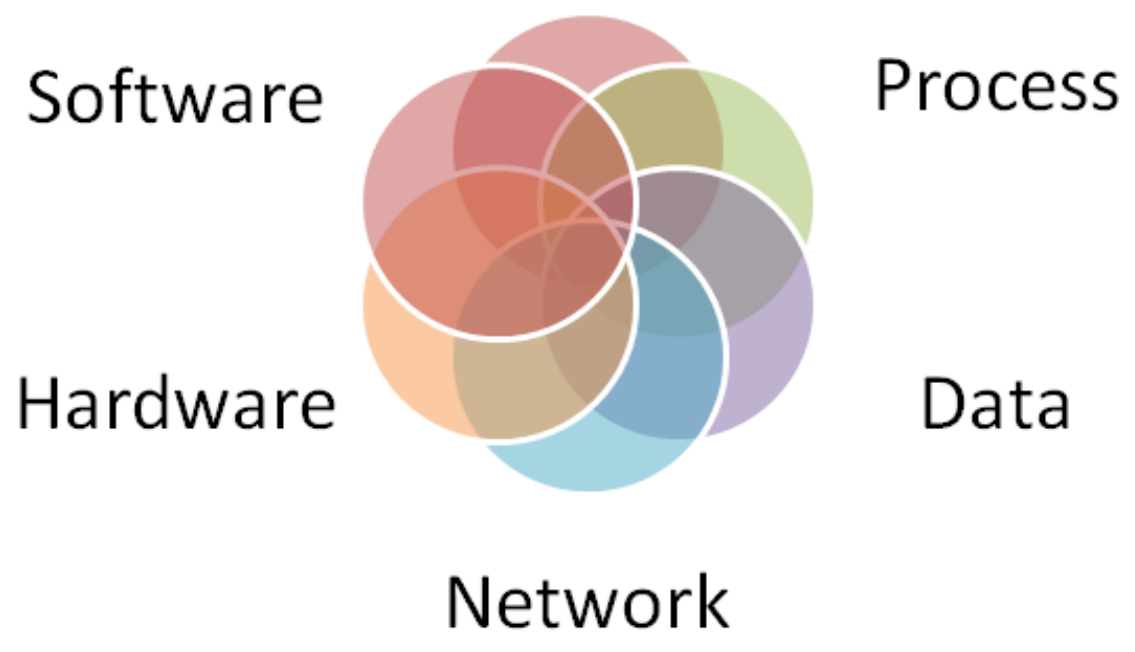


OAJIS

Journal of

Information

Systems

is.its.ac.id/pubs/oajis/

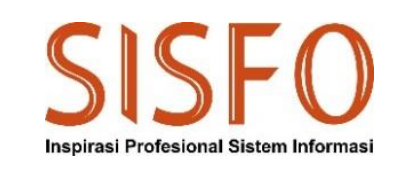

Jurnal Sisfo Vol. 08 No. 03 (2019) i-ii

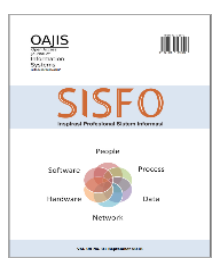

\section{Pimpinan Redaksi}

Faizal Mahananto

\section{Dewan Redaksi}

Eko Wahyu Tyas Darmaningrat

Amna Shifia Nisafani

Arif Wibisono

Rully Agus Hendrawan

\section{Tata Pelaksana Usaha}

\section{Achmad Syaiful Susanto}

Rini Ekowati

\section{Sekretariat}

Departemen Sistem Informasi - Fakultas Teknologi Informasi dan Komunikasi

Institut Teknologi Sepuluh Nopember (ITS) - Surabaya

Telp. 031-5999944 Fax. 031-5964965

Email: editor@jurnalsisfo.org

Website: http://jurnalsisfo.org

Jurnal SISFO juga dipublikasikan di Open Access Journal of Information Systems (OAJIS)

Website: http://is.its.ac.id/pubs/oajis/index.php 
OAJIS

Journal of

Information

Systems

is.its.ac.id/pubs/oajis/

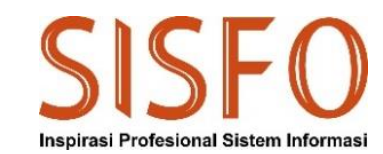

Jurnal Sisfo Vol. 08 No. 03 (2019) i-ii

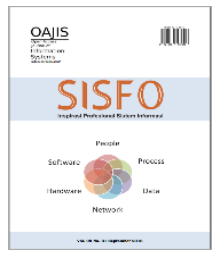

\section{Mitra Bestari}

Nur Aini Rakhmawati, Ph.D. (Institut Teknologi Sepuluh Nopember)

Rahadian Bisma, M.Kom. ITILF. (Universitas Negeri Surabaya)

Raras Tyasnurita, S.Kom, M.BA, Ph.D. (Institut Teknologi Sepuluh Nopember)

Satria Fadil Persada, S.Kom, M.BA, Ph.D (Institut Teknologi Sepuluh Nopember)

Sholiq, S.T, M.Kom, M.SA. (Institut Teknologi Sepuluh Nopember) 


\section{OAJIS \\ Open Access \\ Information \\ Systems \\ is.its.ac.id/pubs/oajis/}

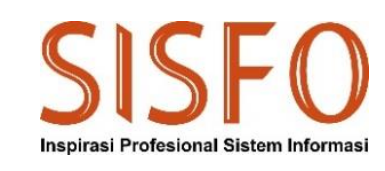

Jurnal Sisfo Vol. 08 No. 03 (2019) iii

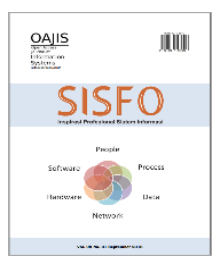

\section{Daftar Isi}

Identifikasi Karakteristik Teknik Elisitasi pada Rekayasa Kebutuhan Perangkat Lunak: Sebuah Review Sistematis

Endang Sulistiyani, Sasmi Hidayatul Yulianingtyas

Model Sistem Teleradiologi untuk Akses Pelayanan Kesehatan Rujukan

Romeo, Agus Sujadi

Integrasi Algoritma Blowfish untuk Pengamanan Data pada File MP3 dengan Steganografi LSB

Bonifacius Vicky Indriyono

Penyusunan Panduan Perawatan Software dan Hardware Pemerintah Kota Madiun Berdasarkan ISO/IEC 14764:2006 dan ITIL V3 2011

Umi Ridhoi, Anisah Herdiyanti, Tony Dwi Susanto.

Pengaruh Teknologi Informasi dalam Pertukaran Informasi dan Integrasi Rantai Pasok terhadap Performa Rantai Pasok

Achmad Wildan Nabila, Mahendrawathi ER 206 
Halaman ini sengaja dikosongkan 


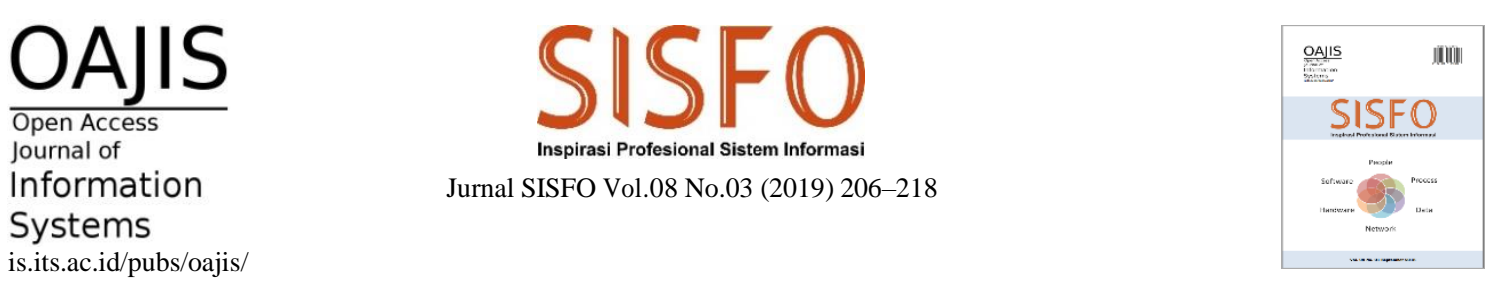

\title{
Pengaruh Teknologi Informasi dalam Pertukaran Informasi dan Integrasi Rantai Pasok terhadap Performa Rantai Pasok
}

\author{
Achmad Wildan Nabila*, Mahendrawathi ER. \\ Departemen Sistem Informasi, Fakultas Teknologi Informasi dan Komunikasi, Institut Teknologi Sepuluh Nopember
}

\begin{abstract}
Supply chain management is a method to manage networks of companies that work together to create and deliver a product to the end user. From previous research, it is known that one of the conditions of intensive coordination is the information sharing that has been facilitated well with Information Technology (IT). Various studies have been conducted related to three constructs: topics on the use of IT, information sharing, and supply chain integration on supply chain performance. However, previous research didn't discuss the interrelationship between these topics. Whereas, this needs to be discussed simultaneously related to its relation to supply chain performance. Therefore, a structured research study is conducted to identify any indicators that can be measured to determine the impact of the three constructs on supply chain performance. This paper uses the systematic literature review (SLR) method. The final result obtained from this SLR is the extraction of data from selected journals that are in accordance with the review question, that is the measurement indicators of the third variable of the construct.
\end{abstract}

Keywords: Information Sharing, Information Technology, Supply Chain Integration, Supply Chain Performance

\begin{abstract}
Abstrak
Manajemen rantai pasok adalah sebuah metode untuk mengelola jaringan perusahaan-perusahaan yang bekerja bersama untuk menciptakan dan mengirimkan suatu produk ke pemakai akhir. Dari penelitian terdahulu, diketahui bahwa salah satu syarat dari koordinasi yang intensif adalah pertukaran informasi yang didukung oleh penggunaan Teknologi Informasi (TI) dengan baik. Berbagai penelitian telah dilakukan terkait tiga konstruk yaitu: topik penggunaan TI, pertukaran informasi, dan integrasi rantai pasok terhadap performa rantai pasok. Namun, penelitian terdahulu tidak membahas keterkaitan antar topik tersebut. Sedangkan, hal tersebut perlu dibahas secara simultan terkait hubungannya terhadap performa rantai pasok. Oleh karena itu, dilakukan kajian penelitian terstruktur untuk mengidentifikasi indikator-indikator apa saja yang dapat diukur untuk mengetahui dampak dari ketiga konstruk tersebut terhadap performa rantai pasok. Paper ini menggunakan metode systematic literature review (SLR). Hasil akhir yang didapatkan dari SLR ini adalah ekstraksi data dari beberapa jurnal terpilih yang sesuai dengan review question yaitu indikatorindikator pengukuran variabel ketiga konstruk tersebut.
\end{abstract}

Kata kunci: Integrasi Rantai Pasok, Pertukaran Informasi, Performa Rantai Pasok, Teknologi Informasi

(C) 2019 Jurnal SISFO.

Histori Artikel: Disubmit 12-05-2019; Direvisi 25-05-2019; Diterima 20-05-2018; Tersedia online 31-05-2019

*Corresponding Author

Email address: wildanabil.college@gmail.com (Achmad Wildan Nabila)

https://doi.org/10.24089/j.sisfo.2019.05.005 


\section{Pendahuluan}

Rantai pasok adalah jaringan perusahaan-perusahaan yang bekerja secara bersama-sama untuk menciptakan dan mengantarkan suatu produk ke tangan pemakai akhir (pemasok, pabrik, distributor, toko atau ritel, dan perusahaan-perusahaan pendukung seperti perusahaan penyedia jasa logistik). Jaringan perusahaan tersebut harus dikelola dengan baik, proses pengelolaan ini biasa disebut sebagai manajemen rantai pasok. Manajemen rantai pasok yang baik membutuhkan koordinasi yang intensif antar rantai pasoknya. Dari penelitian terdahulu diketahui bahwa syarat dasar dari koordinasi yang intensif adalah pertukaran informasi, yang telah difasilitasi dengan baik dengan teknologi informasi [1].

Pertukaran informasi berarti membagi informasi penting kepada sistem, orang, atau unit organisasi. Untuk meningkatkan hasil dari pertukaran informasi, organisasi harus menjawab 4 pertanyaan utama: pertama kita bertanya tentang informasi apa yang dibagikan, lalu dengan siapa informasi dibagikan, bagaimana informasi dibagikan, dan terakhir kapan informasi dibagikan [2]. Kualitas dari jawaban akan membantu dalam menghindari redundansi, mengurangi biaya, dan meningkatkan respon [3]. Pertukaran informasi dalam rantai pasok dapat membawa banyak keuntungan bagi perusahaan, sebagai contoh, produk sesuai dengan permintaan pelanggan dan perubahan di pasar dapat diantisipasi. Nilai sesungguhnya dari pertukaran informasi dalam rantai pasok dapat didefinisikan oleh fakta bahwa keuntungan yang didapatkan mempertimbangkan keterlibatan biaya. Biaya ini termasuk investasi sistem informasi dan ongkos untuk pelanggan atau pemasok dalam menyediakan informasi, biaya koordinasi termasuk biaya komunikasi dan administrasi. Biaya-biaya ini dapat dikurangi dengan pengembangan Teknologi Informasi (TI) terkini, seperti Enterprise Resource Planning (ERP) dan teknologi web [4].

Proses pertukaran informasi tentunya tidak bisa berjalan dengan lancar hanya dengan mengandalkan fasilitas Teknologi Informasi (TI), dibutuhkan juga suatu koordinasi dan kontribusi yang baik antar rantai pasok atau integrasi rantai pasok. Integrasi rantai pasok meningkatkan pertukaran informasi berdasarkan kepercayaan [5]. Dengan memperdalam hubungan berbasis kepercayaan antar pihak dalam rantai pasok, perusahaan dapat meningkatkan durasi kontrak di antara mitra-mitra rantai pasok, dapat mendorong penyelesaian konflik yang efisien, dapat meningkatkan daya tanggap pelanggan dan fleksibilitasnya. Akibatnya, aliran informasi melalui rangsangan akan rasa memiliki dan kemauan untuk berbagi juga meningkat.

Berbagai penelitian telah dilakukan terkait topik penggunaan TI, pertukaran informasi, dan integrasi rantai pasok terhadap performa rantai pasok. Huo [6] menyatakan bahwa koordinasi rantai pasok dengan pemasok dan pelanggan dapat meningkatkan performa rantai pasok. Teknologi informasi dan perjanjian hubungan kerjasama adalah faktor-faktor yang mempengaruhi koordinasi rantai pasok. Kim [5] mengindentifikasi bahwa pertukaran informasi meningkatkan performa rantai pasok dari keseluruhan biaya inventori dan laju pemenuhan ketika variasi permintaan kecil. Huo et al. [6] melakukan penelitian dengan tujuan untuk memeriksa hubungan sebab akibat antara praktik manajemen rantai pasok, kemampuan bersaing, tingkat integrasi rantai pasok, dan performa rantai pasok. Singh dan Teng [7] melakukan penelitian dengan berfokus pada lima faktor menonjol, yaitu integrasi TI, kepercayaan inter-organizational, tata kelola relasional, biaya transaksi, dan performa rantai pasok. Sedangkan Kumar et al. [8] telah membangun sebuah konsep framework berdasarkan literatur dan mendefinisikan empat konstrak dari integrasi (pelanggan, pemasok, internal, dan integrasi informasi) untuk melihat bagaimana hal itu akan meningkatkan performa rantai pasok (seperti fleksibilitas produksi, perubahan inventori, laju pemenuhan pesanan, biaya total logistik, dan performa operasional). Penelitian terdahulu membahas hubungan antar dua konstruk. Sedangkan terdapat keterkaitan antara penggunaan TI, pertukaran informasi dan integrasi rantai pasok yang perlu dibahas secara simultan. Sehingga, peneliti melakukan kajian penelitian terstruktur untuk mengidentifikasi indikatorindikator apa saja yang dapat diukur untuk mengetahui dampak dari penggunaan TI, pertukaran informasi, dan integrasi rantai pasok terhadap performa rantai pasok. Terdapat beberapa kontribusi yang akan diberikan dari penelitian ini baik di bidang keilmuan maupun di bidang praktisi. Di bidang keilmuan, penelitian ini diharapkan dapat menambahkan referensi dan sumber informasi khususnya bagi peneliti yang akan melakukan penelitian sejenis untuk dapat dikembangkan lebih lanjut dan lebih detail pada masa yang akan 
datang. Sedangkan di bidang praktisi, hasil dari penelitian ini akan memberikan sumbangan pemikiran yang dapat digunakan sebagai referensi bagi pihak terkait dalam mengambil alternatif kebijakan dengan tujuan untuk meningkatkan performa rantai pasok.

\section{Metodologi}

Metode literature review yang diadopsi oleh peneliti adalah systematic literature review, yaitu metode untuk mencari literatur penelitian yang sesuai dengan topik penelitian dan dilakukan secara terstruktur. Adapun tahapan dalam melakukan systematic literature review adalah mengidentifikasi focus review, mencari dan memetakan bukti yang tersedia. Langkah kedua dengan menentukan review question. Kemudian mengidentifikasi studi untuk dimasukkan dalam review. Setelah mendapat beberapa jurnal dari beberapa database jurnal, dapat dilakukan langkah keempat, yaitu ekstraksi data dan penilaian kualitas studi. Sehingga, dapat dilakukan proses sintesis untuk menemukan penemuan-penemuan yang sesuai dengan review question. Langkah terakhir adalah dengan melaporkan hasil review [9].

\subsection{Penentuan Tujuan}

Penelitian ini bertujuan untuk mereview analisis-analisis dari penelitian yang berkonteks pada empat variabel, yaitu penggunaan teknologi informasi, pertukaran informasi, integrasi rantai pasok, dan performa rantai pasok. Review pada penelitian ini berfokus pada indikator apa saja yang dinilai atau diukur pada setiap variabel. Indikator-indikator ini dapat diketahui dari data yang berhubungan dengan kuesioner yang disajikan pada tiap jurnal terpilih. Systematic literature review memungkinkan peneliti untuk memperoleh gambaran dan pemahaman dari hubungan antara penggunaan teknologi informasi, pertukaran informasi, integrasi rantai pasok, dan performa rantai pasok.

\subsection{Penentuan Review Question}

Untuk memberikan gambaran umum mengenai paper review ini, review questions yang akan dibahas adalah sebagai berikut:

1) RQ1: Apa saja indikator yang digunakan untuk mengukur tingkat penggunaan TI pada rantai pasok?

2) RQ2: Apa saja indikator yang digunakan untuk mengukur tingkat pertukaran informasi pada rantai pasok?

3) RQ3: Apa saja indikator yang digunakan untuk mengukur tingkat integrasi rantai pasok pada rantai pasok?

4) RQ4: Apa saja indikator yang digunakan untuk mengukur tingkat performa rantai pasok?

Penggunaan TI (Teknologi Informasi) menjelaskan tentang berbagai macam perangkat lunak dan perangkat keras yang digunakan dalam setiap proses rantai pasok untuk memenuhi tujuan bisnis organisasi. Pertukaran informasi menjelaskan tentang pertukaran data diantara beberapa organisasi, orang, dan teknologi. Integrasi rantai pasok menjelaskan tentang rantai pasok-rantai pasok yang terintegrasi melakukan pekerjaan dibawah sistem yang sama dan alur yang sesuai. Sedangkan performa rantai pasok menjelaskan tentang hasil dari kinerja rantai pasok berupa ketersediaan stok dan pengiriman barang yang sesuai dengan jadwal.

Dari review question yang telah disebutkan, peneliti menentukan key data for review yang terdiri dari criteria of inclusion and exclusion article, data search, data selection dan extract data. Tabel 1 merupakan penjelasan dari masing-masing key data for review. Proses pencarian data berupa makalah menggunakan dua database pencarian, yaitu ScienceDirect dan EmeraldInsight. Peneliti memilih kedua database tersebut karena peneliti memiliki hak akses penuh untuk melakukan pencarian dan pengunduhan makalah dari database ScienceDirect dan EmeraldInsight. 
Tabel 1. Key data for review

\begin{tabular}{ll}
\hline \multicolumn{1}{c}{ Key data for review } & \multicolumn{1}{c}{ Description } \\
\hline Criteria of Inclusion and Exclusion Article & Based on year, language, main analysis, context, journal \\
Data Search & ScienceDirect, EmeraldInsight \\
Data Selection & Total search from database will undergo quality assessment of papers \\
Extract Data & Title, author information, year, purpose, result \\
\hline
\end{tabular}

\subsection{Penentuan Karakteristik Studi Primer}

Menentukan karakteristik dari paper yang ditemukan dapat dilakukan dengan inklusi dan eksklusi. Peneliti telah menentukan kriteria inklusi dan eksklusi sesuai dengan RQ yang dapat dilihat pada Tabel 2. Pemilihan keyword pencarian pada database berdasarkan keyword umum yang sering digunakan dalam penelitian terdahulu. Peneliti memilih keyword information technology, information sharing, supply chain integration, dan supply chain performance karena telah banyak digunakan oleh penelitian sebelumnya meskipun terdapat banyak sinonim dari keyword-keyword tersebut.

Table 2. Criteria of inclusion and exclusion

\begin{tabular}{|c|c|}
\hline Criteria & Description \\
\hline $\begin{array}{l}\text { Inclusion } \\
\text { Paper }\end{array}$ & $\begin{array}{l}\text { Jurnal yang menggunakan kata kunci "information technology", "information sharing", "supply chain } \\
\text { integration", dan "supply chain performance" } \\
\text { Jurnal internasional } \\
\text { Jurnal yang menggunakan bahasa Inggris } \\
\text { Jurnal yang terbit pada tahun 2014-2019 }\end{array}$ \\
\hline $\begin{array}{l}\text { Exclusion } \\
\text { Paper }\end{array}$ & $\begin{array}{l}\text { Buku } \\
\text { Incomplete records }\end{array}$ \\
\hline
\end{tabular}

\subsection{Pengambilan Sampel Literatur yang Berpotensi}

Pada penelitian ini, peneliti memilih dua database jurnal online untuk mencari literatur jurnal yang kemudian digunakan untuk membuat literature review. Kedua database jurnal online tersebut adalah ScienceDirect dan EmeraldInsight. Kata kunci yang digunakan untuk mencari jurnal di kedua database online tersebut adalah "information technology", "information sharing", "supply chain integration", dan "supply chain performance".

\subsection{Pemilihan Literatur Terkait}

Systematic literature review ini menggunakan tiga tahap dalam menyeleksi jurnal. Pada tahap pertama dilakukan pencarian sesuai keyword pada database jurnal online Sciencedirect dan Emerald Insight. Kemudian tahap kedua dilakukan seleksi jurnal yang didapat dari tahap pertama dengan menggunakan kriteria inklusi dan eksklusi yang telah disebutkan. Tahap terakhir, peneliti melakukan quality assessment terhadap hasil seleksi pada tahap kedua.

\subsection{Sintesis Literatur}

Paper yang telah terkumpul pada tahap seleksi paper selanjutnya akan disintesis sesuai dengan RQ yang telah dijelaskan. Hasil dari sintesis akan disajikan dalam bentuk tabel kemudian diambil kesimpulan. 


\section{Hasil}

Berkaitan dengan tahapan yang telah dijelaskan pada bab metodologi, pada bagian ini akan disajikan hasil yang diperoleh.

\subsection{Hasil Pencarian Paper}

Pada tahap pertama, dengan memasukkan kata kunci "information technology", "information sharing", "supply chain integration", dan "supply chain performance" di database jurnal online Sciencedirect dan Emerald Insight ditemukan 70 jurnal pada database jurnal online ScienceDirect dan 66 jurnal pada database jurnal online EmeraldInsight. Kemudian pada tahap kedua, diterapkan kriteria inklusi dan eksklusi terhadap hasil seleksi jurnal tahap pertama. Pada tahap ini didapatkan 23 jurnal pada database jurnal online ScienceDirect dan 30 jurnal pada database jurnal online Emerald Insight yang sesuai dengan kriteria inklusi dan eksklusi yang telah ditentukan. Tahap terakhir yaitu dengan melakukan quality assessment terhadap hasil seleksi tahap kedua, sehingga didapatkan 8 jurnal dari database jurnal online ScienceDirect dan 9 jurnal dari database jurnal online EmeraldInsight.

Jurnal-jurnal penelitian yang dipilih adalah jurnal-jurnal yang terbit pada tahun 2014 hingga 2019. Terdapat total 17 jurnal yang dipilih yang sesuai dengan tujuan review serta research question dari penelitian. Jurnaljurnal yang terpilih merupakan 8 jurnal dari database jurnal online ScienceDirect dan 9 jurnal dari database jurnal online EmeraldInsight. Gambar 1 berikut ini menunjukkan jumlah jurnal yang telah didapat penulis. Jurnal tersebut dikelompokkan sesuai dengan RQ yang dapat dijawab masing-masing Jurnal.

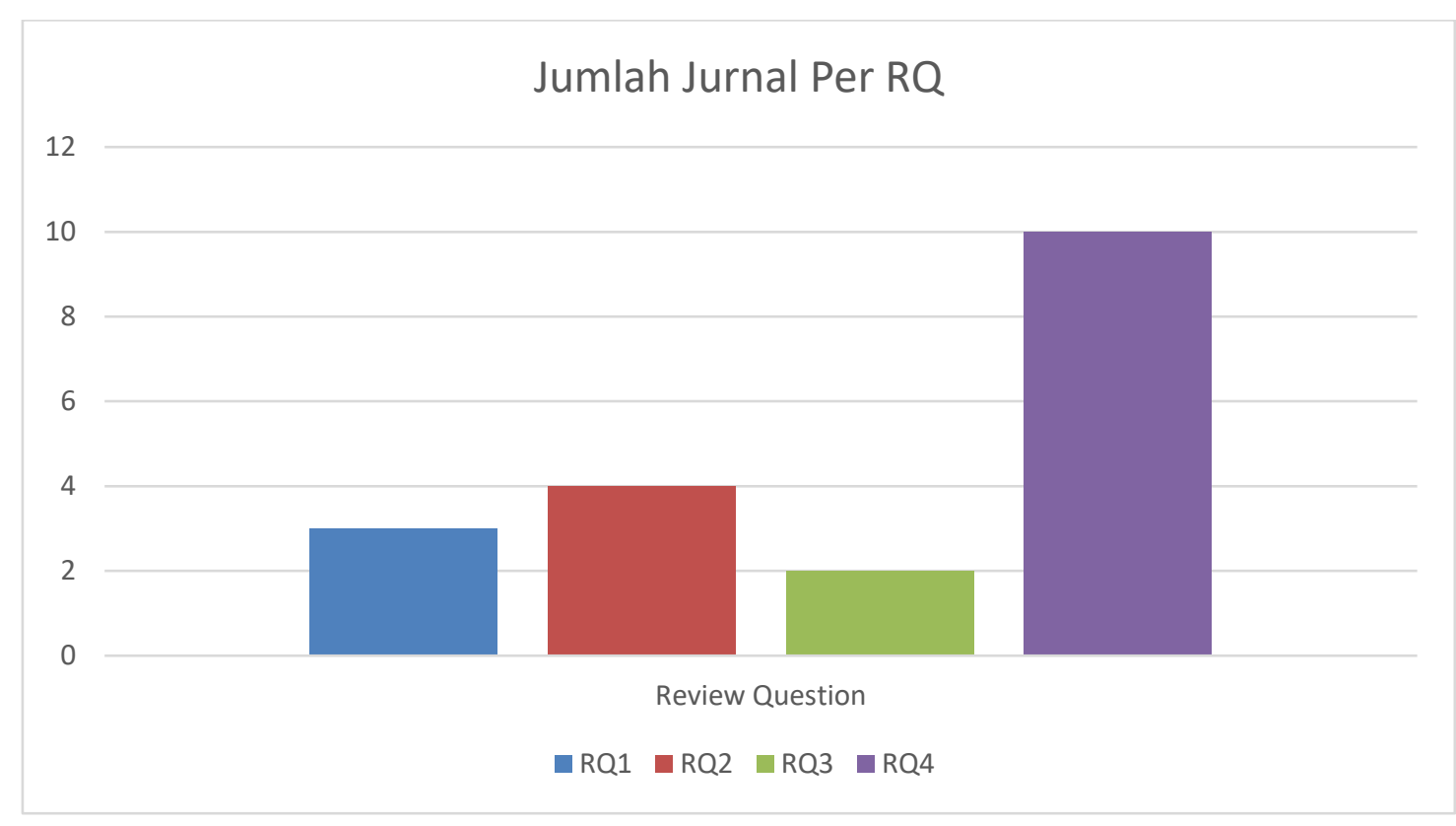

Gambar 1. Jumlah jurnal per RQ

Dari Gambar 1 dapat diketahui bahwa jurnal yang membahas RQ1 sebanyak 3 jurnal, RQ2 sebanyak 4 jurnal, RQ3 sebanyak 2 jurnal, dan RQ4 sebanyak 10 jurnal. RQ4 yang membahas indikator dari performa rantai pasok memiliki jumlah paling banyak yaitu 10 jurnal dari total 17 jurnal yang telah ditemukan sesuai dengan topik review. 
Tiap RQ mempunyai indikator yang berbeda-beda di setiap jurnalnya. Hal ini dikarenakan populasi penelitian yang berbeda. Terdapat 2 macam perusahaan yang disebutkan dalam 17 jurnal tersebut, yaitu perusahaan manufacturing dan perusahaan kesehatan. Dari 17 jurnal tersebut diketahui pula terdapat 3 jurnal yang tidak menyebutkan indikator kuisionernya, dan terdapat 3 jurnal yang menggunakan model simulasi, sehingga tidak menggunakan metode survey atau kuesioner dalam penelitiannya.

\subsection{Indikator yang Digunakan untuk Mengukur Tingkat Penggunaan TI pada Rantai Pasok}

Pentingnya rantai pasok sebagai pemroses produksi dan distribusi yang mengubah material mentah menjadi produk akhir dan mengirimkannya ke pelanggan semakin meningkat. Hal ini dikarenakan perkembangan teknologi informasi dan pendekatan pengembangan proses [10]. Mandal [11] menyatakan bahwa kemampuan teknologi informasi memainkan peranan dominan dalam pertukaran informasi untuk operasi rantai pasok. Penelitian ini mempertimbangkan 3 jenis kemampuan TI, yaitu outside-in, spanning, dan inside-out. Selain itu, Gupta et al. [12] juga telah menguji peran dari layanan ERP pada performa organisasi, performa yang dikategorikan sebagai performa rantai pasok, dan performa organisasi yang menggabungkan performa finansial dan performa pemasaran. Alam et al. [13] menyatakan bahwa penggunaan TI tanpa disertai hubungan yang diperlukan dengan pemasok tidak dapat menghasilkan perubahan yang terukur pada performa rantai pasok. Dari keempat jurnal tersebut, peneliti mendapatkan indikator yang dapat digunakan untuk mengukur tingkat penggunaan TI pada rantai pasok. Indikator tersebut dapat dilihat pada Tabel 3.

\subsection{Indikator yang Digunakan untuk Mengukur Tingkat Pertukaran Informasi pada Rantai Pasok}

Singh dan Teng [7] melakukan penelitian yang bertujuan untuk menguji pengaruh langsung dari integrasi TI, kepercayaan, tata kelola relasional terhadap performa rantai pasok dan untuk memvalidasi hubungan teoritis yang rumit melalui integrasi TI dan kepercayaan menggunakan pengaruhnya pada hasil rantai pasok. Didukung oleh Kaliani et al. [14] dimana ditemukan bahwa integrasi rantai pasok memainkan peranan penting dalam meningkatkan performa rantai pasok. Wu et al. [15] melakukan penelitian dengan tujuan untuk menguji hubungan antara variabel berbasis teori pertukaran sosial, pertukaran informasi, dan kolaborasi serta performa rantai pasok. Penemuan empiris menunjukan bahwa persoalan berbasis teori pertukaran sosial sangat penting untuk menentukan pertukaran informasi dan kolaborasi yang memberikan efek pada performa rantai pasok. Pertukaran informasi yang mempengaruhi peningkatan performa rantai pasok juga ditunjukkan oleh Fuchs et al. [16]. Fuchs et al. [16] melakukan penelitian yang mengindikasi pengaruh kuat dan signifikan dari kemampuan fungsional TI terhadap keunggulan proses internal dan pertukaran informasi yang berubah pada peningkatan performa rantai pasok.

Dominguez et al. [17] menemukan bahwa strategi bernama Order Variance Prioritization (OVAP) untuk membangun struktur pertukaran informasi mempunyai dampak signifikan terhadap performa rantai pasok. Marinagi et al. [18] melakukan penelitian yang bertujuan untuk mengetahui peranan dari pertukaran informasi diantara kualitas informasi dan performa rantai pasok, hasilnya memberikan bukti empiris bahwa pertukaran informasi memiliki dampak mediasi antara kualitas informasi dan performa rantai pasok. Constantino et al. [19] melakukan penelitian untuk mengetahui dampak pertukaran informasi dan koordinasi rantai pasok terhadap performa rantai pasok. Hasil dari penelitian menunjukan pentingnya pertukaran informasi dan interaksinya dengan parameter kontrol ketersediaan, membuktikan bahwa peramalan pesanan mempunyai kontribusi yang signifikan terhadap kestabilan disepanjang rantai pasok. Untuk lebih jelasnya, indikator yang didapat dari jurnal-jurnal tersebut dapat dilihat pada Tabel 3.

\subsection{Indikator yang Digunakan untuk Mengukur Tingkat Integrasi Rantai Pasok pada Rantai Pasok}

Selain dijelaskan mengenai pertukaran informasi pada rantai pasok, Singh dan Teng [7] serta Kaliani et al. [14] juga menjelaskan mengenai tingkat integrasi rantai pasok. Singh dan Teng [7] menyebutkan tujuh indikator yang dapat digunakan untuk mengukur tingkat integrasi rantai pasok. Sedangkan Kaliani et al. [14] 
menyebutkan empat indikator yang juga dapat digunakan untuk mengukur tingkat integrasi rantai pasok. Zhang et al. [20] mendapatkan hasil penelitian bahwa teknologi informasi dan komunikasi pada organisasi inter mempunyai hubungan positif dengan performa rantai pasok dan hubungan ini ditengahi oleh integrasi rantai pasok. Sedangkan untuk organisasi intra, teknologi informasi dan komunikasi menjembatani efek dari integrasi rantai pasok dengan performa rantai pasok. Indikator tersebut dapat dilihat pada Tabel 3.

\subsection{Indikator yang Digunakan untuk Mengukur Tingkat Performa Rantai Pasok}

Seperti yang telah dijelaskan sebelumnya, Singh dan Teng [7], Mandal [11], Gupta et al. [12], Kaliani et al. [14] dan $\mathrm{Wu}$ et al. [15] melakukan penelitian terkait performa rantai pasok. Selain itu, peneliti juga menemukan indikator untuk mengukur tingkat performa rantai pasok pada penelitian yang dilakukan oleh Kumar et al. [8], Gonul et al. [21], Sadegh et al. [22], Shee et al. [23], dan Seo et al. [24]. Kumar et al. [8] membangun framework konseptual dari literatur dan mendefinisikan 4 indikator dari integrasi (pelanggan, pemasok, internal, dan integrasi informasi) untuk melihat bagaimana hal tersebut dapat meningkatkan performa rantai pasok seperti fleksibilitas, produksi, ketersediaan, laju pemenuhan pesanan, total biaya logistik, dan performa operasional. Gonul et al. [21] merancang penelitian dengan menguji cloud computing sebagai pengada sistem manajemen rantai pasok berbasis elektronik yang meningkatkan pertukaran informasi dalam rantai pasok rumah sakit. Model sistem dinamik digunakan untuk mensimulasikan performa dari rantai pasok. Ukuran performa yang dibandingkan adalah rata-rata level ketersediaan, lead time, dan pesanan yang tidak terpenuhi. Kemudian, Sadegh et al. [22] menunjukan bahwa proses manajemen pengetahuan mempunyai dampak signifikan terhadap performa rantai pasok yang secara positif dimoderasi oleh dukungan TI/SI dan integrasi rantai pasok.

Hampir sama dengan Gonul et al. [21] mengenai cloud computing, Shee et al. [23] menunjukkan bahwa teknologi berbasis cloud mempunyai efek positif terhadap integrasi rantai pasok, dan integrasi rantai pasok berhubungan dengan performa rantai pasok. Selanjutnya, Seo et al. [24] menyatakan bahwa keinovatifan dalam rantai pasok mempunyai dampak positif pada integrasi rantai pasok dan performa rantai pasok. Bagaimanapun, dampak langsung dari keinovatifan pada performa rantai pasok menghilang ketika integrasi rantai pasok dimasukkan ke dalam model sebagai mediator. Penemuan menyarankan bahwa keinovatifan dapat mempengaruhi performa rantai pasok hanya ketika level integrasi rantai pasok efektif dalam mengembangkan praktik rantai pasok yang penting. Indikator yang terdapat pada jurnal-jurnal tersebut dapat dilihat pada Tabel 3.

Tabel 3. Indikator sesuai RQ

\begin{tabular}{|c|c|}
\hline Research Question & Indikator per Variabel \\
\hline \multirow{10}{*}{$\begin{array}{l}\text { Information Technology } \\
\text { (RQ1) }\end{array}$} & Intranet \& internet [10] \\
\hline & Computers \& engineering [10] \\
\hline & Planning \& systems [10] \\
\hline & Outside-in [11] \\
\hline & Spanning [11] \\
\hline & Inside-out [11] \\
\hline & Selection of ERP package [12] \\
\hline & IT (Information Technology) infrastructure [12] \\
\hline & Data integrity \& system testing [12] \\
\hline & Functionality [12] \\
\hline
\end{tabular}




\begin{tabular}{|c|c|}
\hline Research Question & Indikator per Variabel \\
\hline \multirow{14}{*}{$\begin{array}{l}\text { Information Sharing } \\
\text { (RQ2) }\end{array}$} & Relationship with supplier provide any information [7] \\
\hline & Exchange of information takes place frequently [7], [14] \\
\hline & The parties will provide proprietary information [7], [14] \\
\hline & The parties keep each other informed about events or changes [7], [14] \\
\hline & Keep informed about issues that affect its business [14] \\
\hline & Share business knowledge [14] \\
\hline & Inventory data are visible [15] \\
\hline & Production \& delivery data are shared [15] \\
\hline & Actual sale data are visible [15] \\
\hline & Demanding forecast are shared [15] \\
\hline & Performance metrics are shared [15] \\
\hline & IS (Information Sharing) quality to suppliers \& OEMs (Original Equipment Manufacturers) [16] \\
\hline & IS (Information Sharing) quality from suppliers \& OEMs (Original Equipment Manufacturers) [16] \\
\hline & $\begin{array}{l}\text { IS (Information Sharing) frequency with suppliers \& OEMs (Original Equipment Manufacturers) } \\
\text { [16] }\end{array}$ \\
\hline \multirow{11}{*}{$\begin{array}{l}\text { Integrasi Rantai Pasok } \\
\text { (RQ3) }\end{array}$} & Shipping [7] \\
\hline & Inventory control for material [7] \\
\hline & Finished goods inventory [7] \\
\hline & Production schedules [7] \\
\hline & Anticipated demand [7] \\
\hline & Monitoring \& coordinating performance \& activities [7] \\
\hline & Sharing databases, applications \& files [7] \\
\hline & Establish more frequent contact with each other [14] \\
\hline & Create a compatible communication and IS (Information Sharing) [14] \\
\hline & Extends its SC (Supply Chain) beyond its customers/suppliers [14] \\
\hline & Participate in the marketing efforts of its customers [14] \\
\hline \multirow{11}{*}{$\begin{array}{l}\text { Performa Rantai Pasok } \\
\text { (RQ4) }\end{array}$} & Supply operations for component has improved [7] \\
\hline & Without supplier the supply operation for component would not perform as well [7] \\
\hline & Inventory turnover has improved [7], [8], [24] \\
\hline & Relationship with supplier has improved coordination [7], [14] \\
\hline & Relationship with supplier helped us (companies) get better prices [7] \\
\hline & Production flexibility [8] \\
\hline & Order fulfillment rate [8] \\
\hline & Total logistics costs [8], [24] \\
\hline & Operational performance [8] \\
\hline & Key processes in SC (Supply Chain) is improving [11] \\
\hline & The flow of patient in SC (Supply Chain) is improving [11] \\
\hline
\end{tabular}




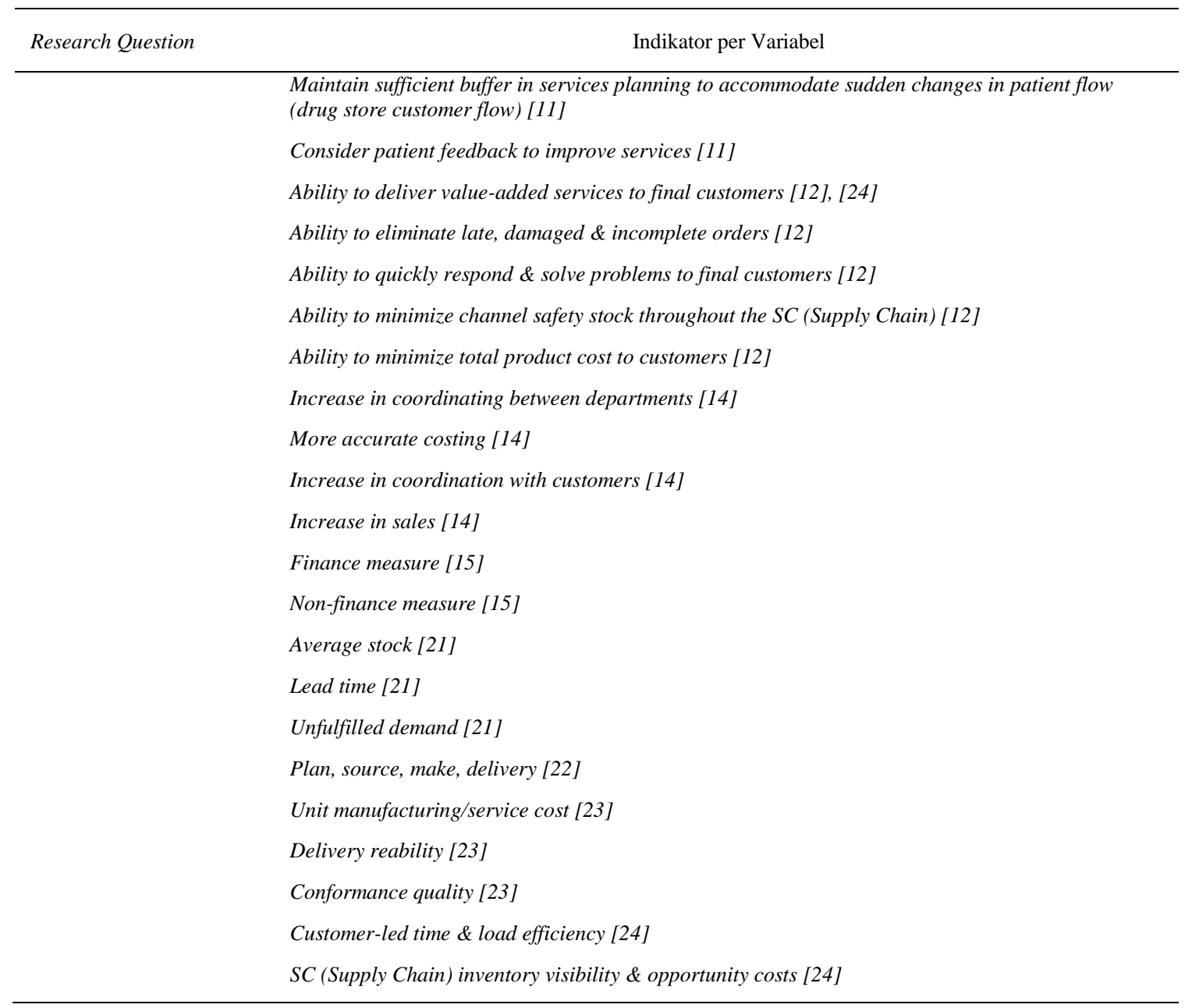

Tabel 3 merupakan daftar indikator-indikator yang digunakan dalam penelitian sebelumnya mengenai penggunaan TI, pertukaran informasi, integrasi rantai pasok, dan performa rantai pasok. Indikator-indikator di atas didapatkan dari jurnal-jurnal terpilih yang sesuai dengan topik penelitian ini dan tidak hanya membahas tentang 1 konstruk saja, melainkan hubungan antar lebih dari 1 konstruk penelitian.

\section{Pembahasan}

Dengan melakukan literatur review yang disintesis, maka peneliti dapat membuat diagram konseptual yang dibangun dari empat konstruk. Konstruk-konstruk tersebut adalah Penggunaan Teknologi Informasi, Integrasi Rantai Pasok, Pertukaran Informasi, dan Performa Rantai Pasok. Hipotesis penelitian dalam penelitian ini terdiri dari lima hipotesis berdasarkan research question yang telah ditentukan. Research question penelitian ini adalah untuk menemukan indikator-indikator yang secara umum digunakan dalam mengukur tingkat penggunaan TI, pertukaran informasi, integrasi rantai pasok, dan performa rantai pasok. Berdasarkan Tabel 3, indikator-indikator tersebut berhasil ditemukan dari 17 jurnal terpilih. Jurnal-jurnal terpilih membahas tidak hanya tentang 1 konstruk, namun juga membahas hubungan antar lebih dari 1 konstruk. Oleh karena itu, peneliti dapat membuat beberapa hipotesis berdasarkan indikator-indikator yang telah ditemukan dan hubungan antar konstruk yang dibahas di tiap jurnalnya. 
Teknologi informasi memainkan peranan dominan dalam pertukaran informasi untuk operasi rantai pasok [11][20][23]. Menurut Fuchs et al. [16] kemampuan fungsional TI mendukung pertukaran informasi. Sedangkan, Marinagi et al. [18] menyatakan bahwa pertukaran informasi berhubungan positif dengan performa rantai pasok. Hubungan ketiga variabel tersebut dapat membentuk suatu hubungan konseptual baru, yaitu hubungan penggunaan TI untuk pertukaran informasi terhadap performa rantai pasok dengan arah panah dari TI ke arah pertukaran informasi, lalu dari pertukaran informasi ke arah performa rantai pasok.

Shee et al. [23] mengatakan bahwa teknologi berbasis cloud mempunyai efek positif terhadap integrasi rantai pasok. Sedangkan integrasi rantai pasok berhubungan positif dengan performa rantai pasok [14][20][23]. Hubungan ketiga variabel tersebut juga dapat membentuk suatu hubungan konseptual baru, yaitu hubungan penggunaan TI untuk integrasi rantai pasok terhadap performa rantai pasok dengan arah panah dari TI ke arah integrasi rantai pasok, lalu dari integrasi rantai pasok ke arah performa rantai pasok.

Dari pernyataan-pernyataan diatas TI digunakan untuk mempengaruhi performa rantai pasok secara tidak langsung melalui variabel mediasi. Namun Fuchs et al. [16] mengatakan bahwa kemampuan TI dapat mendorong keunggulan proses rantai pasok internal. Sehingga, kemampuan TI dapat mempengaruhi performa rantai pasok secara langsung dan membentuk hubungan konseptual baru dengan arah panah dari TI menuju ke arah performa rantai pasok. Berikut adalah hipotesis yang diperoleh peneliti sehingga dapat membentuk diagram konseptual pada Gambar 2.

1) $\mathrm{H} 1=$ terdapat hubungan signifikan antara penggunaan TI dan integrasi rantai pasok.

2) $\mathrm{H} 2=$ terdapat hubungan signifikan antara penggunaan TI dan pertukaran informasi.

3) $\mathrm{H} 3=$ terdapat hubungan signifikan antara penggunaan TI dan performa rantai pasok.

4) $\mathrm{H} 4=$ terdapat hubungan signifikan antara integrasi rantai pasok dan performa rantai pasok.

5) $\mathrm{H} 5=$ terdapat hubungan signifikan antara pertukaran informasi dan performa rantai pasok.

Gambar 2 merupakan diagram konseptual yang terbentuk berdasarkan hipotesis hubungan antara keempat konstruk tersebut.

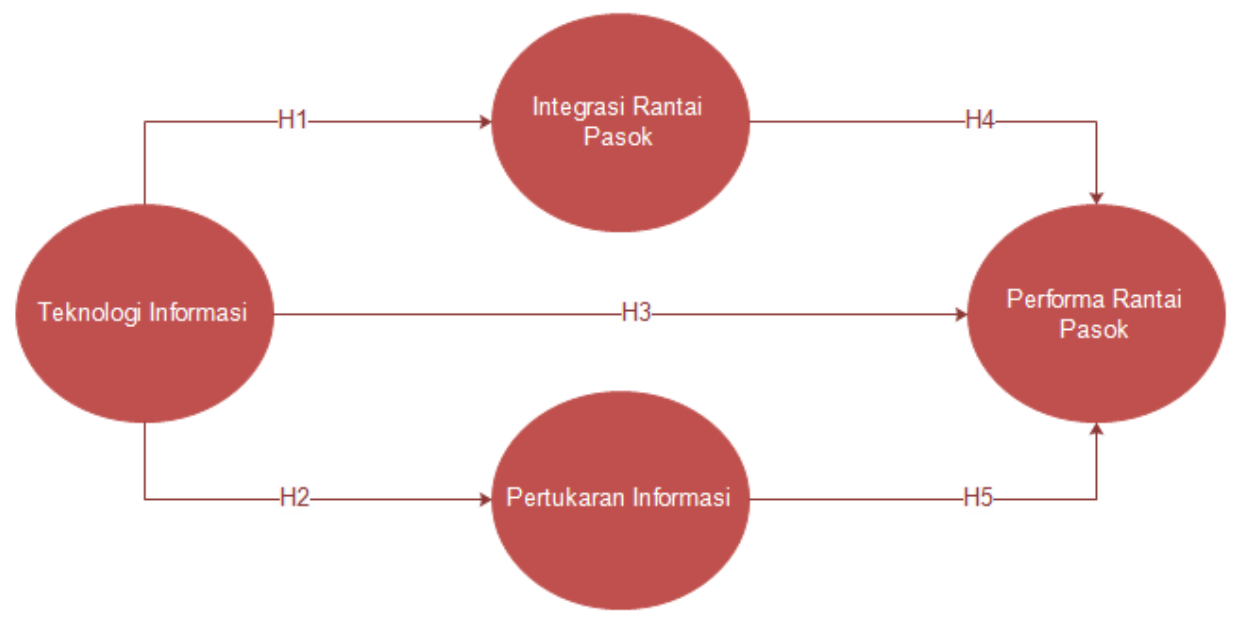

Gambar 2. Diagram konseptual

Gambar 2 menjelaskan hubungan konseptual dari tiap konstruk penelitian. Teknologi Informasi, Integrasi Rantai Pasok, dan Performa Rantai Pasok memiliki hubungan positif (H1 dan H4). Teknologi Informasi, Pertukaran Informasi, dan Performa Rantai Pasok memiliki hubungan positif (H2 dan H5). Teknologi Informasi juga memiliki hubungan positif secara langsung terhadap Performa Rantai Pasok (H3). 


\section{Kesimpulan}

Adapun kesimpulan dari hasil penelitian ini dan saran yang dapat penulis berikan untuk penelitian mendatang adalah sebagai berikut.

\subsection{Simpulan}

Systematic literature review digunakan untuk mencari dan mendapatkan referensi-referensi jurnal yang berguna sebagai dasar pengetahuan dalam membangun sebuah penelitian. Pada literature review di atas, terdapat empat kata kunci utama yang digunakan peneliti dalam mencari jurnal, yaitu information technology, information sharing, supply chain integration, dan supply chain performance. Pada tahap pertama, peneliti mendapatkan 136 jurnal dari database jurnal online ScienceDirect dan EmeraldInsight. Kemudian pada tahap kedua, dilakukan penentuan kriteria inklusi dan eksklusi dan didapatkan 45 jurnal dari database jurnal online ScienceDirect dan EmeraldInsight. Pada tahap terakhir, dilakukan quality assessment dengan cara pemberian bobot pada tiap jurnal hasil seleksi jurnal tahap kedua dan didapatkan 17 jurnal dari database jurnal online ScienceDirect dan EmeraldInsight. Dengan melakukan systematic literature review, peneliti dapat menemukan pengetahuan-pengetahuan baru terkait dengan indikator-indikator apa saja yang dapat diadopsi untuk mengukur variabel-variabel penelitian, sehingga research question dari penelitian dapat terjawab. Hasil dari literature review ini dapat mempermudah peneliti dalam mendesain model konseptual hubungan antara variabel, sehingga hasil yang ingin dicapai peneliti dapat dipahami dengan lebih baik dan dapat digunakan sebagai landasan untuk penelitian selanjutnya.

\subsection{Saran}

Dari hasil penelitian yang dilakukan didapat saran-saran yang perlu ditindak lanjuti untuk pengembangan penelitian selanjutnya:

1) Menggunakan model yang dikembangkan, dapat dilakukan penelitian lanjutan dengan menggunakan kuisioner yang dapat disebar ke banyak perusahaan untuk melakukan analisis terkait hubungan penggunaan TI, pertukaran informasi, dan integrasi rantai pasok terhadap performa rantai pasok.

2) Menggunakan dasar model yang dikembangkan, dapat dibangun model struktural dan model pengukuran penelitian untuk mendapatkan indikator-indikator pengukuran yang lebih detail.

\section{Daftar Rujukan}

[1] H. L. Lee, and S. Whang, "Information sharing in a supply chain," International journal of manufacturing technology and management, vol. 1, no. 1., pp. 79-93, 2000.

[2] Z. Lotfi, M. Mukhtar, S. Sahran, and A.T. Zadeh, "Information sharing in supply chain management," Procedia Technology, vol. 11., pp. 298-304, 2013.

[3] S. Sun, and J. Yen, "Information supply chain: a unified framework for information sharing," Intelligence and Security Informatics., pp. 422-428, 2005.

[4] J. Li, M.J. Shaw, R.T. Sikora, G.W. Tan, and R. Yang, "The effects of information sharing strategies on supply chain performance," College of Commerce and Business Administration., pp. 34, 2001.

[5] S.W. Kim, "An investigation on the direct and indirect effect of supply chain integration on firm performance," International Journal of Production Economics, vol. 119., pp. 328-346, 2009.

[6] B. Huo, C. Zhang, and X. Zhao, "The effect of IT and relationship commitment on supply chain coordination: a contingency and configuration approach," Information and Management, vol. 52, no. 6., 728-740, 2015.

[7] A. Singh, and J.T.C. Teng, "Enhancing supply chain outcomes through information technology and trust," Computers in Human Behavior, vol. 54., 290-300, 2016.

[8] V. Kumar, E.N. Chibuzo, J.A. Garza-Reyes, A. Kumari, L. Rocha-Lona, and G.C. Lopez-Torres, "The impact of supply chain integration on performance: evidence from the UK food sector," Procedia Manufacturing, vol. 11., pp. 814-821, 2017.

[9] J. Poppay, M. Rodgers, L. Arai, and N. Britten, Guidance on the conduct of narrative synthesis in systematic reviews: a product from the ESRC methods programme, 1st ed. Readng, MA: Mark Rodgers, 2006. [E-book] Available: https://www.researchgate.net/publication/233866356. 
[10] A.Z. Acar, and M.B. Uzunlar, "The effect of process development and information technology on time-based supply chain performance," Procedia - Social and Behavioral Sciences, vol. 150., pp. 744-753, 2014.

[11] S. Mandal, "Influence of human capital on healthcare agility and healthcare supply chain performance," Journal of Business and Industrial Marketing, vol. 33, no. 7., pp. 1012-1026, 2018.

[12] S. Gupta, K. Sameer, S.K. Singh, C. Foropon, and C. Chandra, "Role of cloud ERP on the performance of an organization: contingent resource-based view perspective," International Journal of Logistics Management, vol. 29, no. 2., pp. 659-675, 2018.

[13] A. Alam, P.K. Bagchi, B. Kim, S. Mitra, and F. Seabra, "The mediating effect of logistics integration on supply chain performance," The International Journal of Logistics Management, vol. 25, no. 3., pp. 553-580, 2014.

[14] V.P.K. Sundram, V.G.R. Chandran, and M.A. Bhatti, "Supply chain practices and performance: the indirect effect of supply chain integration," Benchmarking, vol. 23, no. 6., pp. 1445-1471, 2016.

[15] I.L. Wu, C.H. Chuang, and C.H. Hsu, "Information sharing and collaborative behaviors in enabling supply chain performance: a social exchange perspective," International Journal of Production Economics, vol. 148., pp. 122-132, 2014.

[16] C. Fuchs, D. Beck, B. Lienland, and F. Kellner, "The role of IT in automotive supplier supply chains," Journal of Enterprise Information Management, vol. 31, no. 1., pp. 64-88, 2017.

[17] R. Dominguez, S. Cannella, A.P. Barbosa-Povoa, and J.M. Framinan, "OVAP: a strategy to implement partial information sharing among supply chain retailers," Transportation Research Part E: Logistics and Transportation Review, vol. 110., pp. 122-136, 2018.

[18] C. Marinagi, P. Trivellas, and P. Reklitis, "Information quality and supply chain performance: the mediating role of information sharing." Procedia - Social and Behavioral Sciences, vol. 175., pp. 473-479, 2015.

[19] F. Constantino, G.G. Di, A. Shaban, and M. Tronci, "The impact of information sharing and inventory control coordination on supply chain performances," Computers and Industrial Engineering, vol. 76., pp. 292-306, 2014.

[20] X. Zhang, D.P.V. Donk, and T.V.D. Vaart, "The different impact of inter-organizational ICT on supply chain performance." International Journal of Operations \& Production Management, vol. 36, no. 7., pp. 803-824, 2016.

[21] K.C. Gonul, D.R. Nowicki, B. Sauser, and W.S. Randall, "Impact of cloud-based information sharing on hospital supply chain performance: a system dynamics framework," International Journal of Production Economics, vol. 195., pp. 168$185,2018$.

[22] M. Sadegh, S.R. Reza, and M.R. Zahedi, "The impact of knowledge management processes on supply chain performance," The International Journal of Logistics Management, vol. 26, no. 3., pp. 603-626, 2015.

[23] H. Shee, S.J. Miah, L. Fairfield, and N. Pujawan, "The impact of cloud-enabled process integration on supply chain performance and firm sustainability: the moderating role of top management," Supply Chain Management, vol. 23, no. 6., pp. 500-517, 2018.

[24] Y.J. Seo, J. Dinwoodie, and D.W. Kwak, "The impact of innovativeness on supply chain performance: is supply chain integration a missing link?," Supply Chain Management, vol. 23, no. 6., pp. 500-517, 2014. 
Achmad Wildan Nabila dan Mahendrawathi ER. / Jurnal SISFO Vol.08 No.03 (2019) 206-218

Halaman ini sengaja dikosongkan 
